\title{
Butterflies and Birds at Somme
}

Donald Hooper, Somme, Sask.

Last summer my brother Ronald, and I collected 37 species of butterflies. They are as follows: Great Spangled Fritillary, Mountain Silver Spot, Northwestern Silver Spot, Silver-bordered Fritillary, Chariclea Fritillary, Meadow Fritillary, Pearl Crescent, Green Coma, Gray Coma, American Tortoise-shell, Mourning Cloak, Red Admiral, Cosmopolite, Banded Purple, Prairie Ringlet, Common Wood-nympe, Red-disked Alpine, Common Alpine, Pearly Eye, Spring Azure, Afra Blue, Checkered White, Gray-veined White, Cabbage Butterfly, Clouded Sulphur, Western Sulphur, Pink-edged Sulphur, Orange Sulphur, Pale Swallowtail, Northern Dusky-wing, Sleepy Dusky-wing, Arctic Skipper, Hofomok Skipper, Accius Skipper. We also saw a Vice- roy and a Tiger Swallowtail, but were unable to catch them. Besides these butterflies we have an interesting collection of moths.

In the last three years we have observed 173 species of birds within 15 miles of Somme. Some of the uncommon ones are: Spotted Towhee, Bohemian Waxwing, Brown Thrasher, Bald Eagle, Saw-whet Owl, Willow Ptarmigan, Hooded Merganser, and Blue Goose.

(Editor's Note: The Hooper brothers are to be highly commended on their observations. Most of us would have difficulty in correctly identifying half a dozen of our Saskatchewan butterflies. Likewise the three year record of 173 species of birds is certainly an enviable one.)

\section{Co-operative Bird Migration Study-1953}

This year the Saskatchewan Natural History Society, together with other observers across the continent, is co-operating with J. H. Zimmerman of the Wisconsin Society for Ornithology, in studying the migration patterns of a number of species of birds. It is hoped to enroll enough observers to make this the most intensive migration study ever undertaken. Most of the birds chosen are commonly and easily identified, so every "BLUE JAY" member (whether resident in Saskatchewan or not) is invited to take part.

Most important is the date first seen. If possible, also record dates of increases in numbers, dates of decreases in numbers, last date seen, and relation of migration to weather changes.

THIS STUDY IS RESTRICTED TO THE FOLLOWING SPECIES THIS YEAR: Note: Use the following form, or if you do not wish to cut out this page make a copy of it.

Canada Goose

First Seen Increase Decrease Last Seen

Red-winged Blackbird

Flicker

Myrtle Warbler

White-throated Sparrow

Purple Martin

Chipping Sparrow

Barn Swallow

Yellow Warbler

House Wren

Baltimore Oriole

Eastern Kingbird

Nighthawk

Ruby-throated Hummingbird

Send all reports to L. T. Carmichael, 1077 Garnet St., Regina, by July 1. (Data on other species, for our own files, should be reported on separate sheets of paper). Further east, the Black-and-white Warbler, Redstart, Rosebreasted Grosbeak, Chimney Swift and Wood Pewee are being studied. Data on these species would be appreciated. 